\title{
A Case of Chronic Appendicitis
}

\section{Bir Kronik Apandisit Olgusu}

\author{
Kemal Peker', Kemal Kılıç² \\ ${ }^{1}$ General Surgery Clinics, Palandöken State Hospital, Eryurum, Turkey, ${ }^{2}$ Department of General Surgery, Kafkas University School of \\ Medicine, Kars, Turkey
}

\begin{abstract}
Although some authors resist the definition of chronic appendicitis, it is the chronic inflammation of the appendiceal tissue and sometimes it is also recurrent. The resistance is related to the absence of the classical clinical symptoms and signs observed during the inflammatory process of the appendicitis. It is usually diagnosed following the histo-pathological examination. The operations are mostly indicated with the persistent or recurrent abdominal pain. In this report we aim to present a case of chronic appendicitis and its clinical manifestation.
\end{abstract}

Key words: chronic appendicitis, adult; chronic abdominal pain

\section{ÖZET}

Bazı yazarlar tanıma karșı direnç gösterseler de, kronik apandisit apendiks dokusunun kronik enflamasyonudur ve bazen de tekrarlayıcıdır. Yazarların direnci akut apendisitin enflamatuvar seyri sırasında görülen belirti ve bulguların yokluğu ile ilișkilidir. Kronik apendisit tanısı genellikle histopatolojik inceleme sonrası konulur. Sürekli ve tekrarlayan karın ağrısı ise ameliyat için gerekçeyi olușturur. Bu yazıda bir kronik apendisit olgusu ve klinik özelliklerini sunmayı amaçladık.

Anahtar kelimeler: kronik apandisit, erișkin; kronik karın ağrısı

\section{Introduction}

Severe abdominal pain which may the result of a partial obstruction of the lumen of the appendix in the absence of inflammation is one of the commonest symptoms leading the patients to the emergency service $^{1}$ and acute appendicitis is one of the commonest surgical diseases resulting in an emergency operation. In addition, throughout the world emergency appendectomy is still one of the most frequent operations.

Kemal Peker, Palandöken Devlet Hastanesi, Eræurum, Türkive,
Although, some authors published results of successful conservative treatment options in acute appendicitis, the conservative approach could not take its place in daily practice ${ }^{2}$.

The diagnosis of acute appendicitis depends on the patient's history, and the basic clinical and laboratory findings. Many surgeons prefer the surgical removal of the inflamed appendix, even if the diagnosis is only suspicious. However, one third of the patients have atypical symptoms confusing the diagnosis. In such cases the removal of the appendix is delayed or even not performed $^{3}$. In contrast, earlier diagnosis and operation may prevent the spread of the inflammation and avoid the development of the related complications.

Although, there has been a significant decrease in the acute appendicitis related death rates for the last four decades, despite the advances in daily medical practice the rates appendiceal perforation and appendectomies without appendicitis remain to be high ${ }^{4,5}$.

Although some authors resist the definition of chronic appendicitis, it is the chronic inflammation of the appendiceal tissue and and sometimes it is also recurrent $t^{6}$. The resistance is related to the absence of the classical clinical symptoms and signs observed during the inflammatory process of the appendicitis. It is usually diagnosed following the histo-pathological examination. The operations are mostly indicated with the persistent or recurrent abdominal pain ${ }^{7}$.

In this report we aim to present a case of chronic appendicitis and its clinical manifestation.

\section{Case}

A 28-year-old male patient admitted to hospital with the complaints of abdominal pain, diarrhea and loss 
of appetite. He had been experiencing the abdominal pain after passing stools and losing weight for the last eight months. He had been hospitalized and followed up in different centres for the evaluation of the weight loss of about 5 kilograms.

The previous medical histories of his family and himself were not remarkable. Palpation of the right lower quadrant of the anterior abdominal wall revealed tenderness, however there was not any sign of defence or rebound. General physical examination was unremarkable with the findings of the arterial blood pressure, pulse rate, respiration rate and the rectal temperature as $110 / 70 \mathrm{mmHg}, 72 / \mathrm{min}, 16 /$ min and $36,5{ }^{\circ} \mathrm{C}$, respectively.

Laboratory and imaging work-up included a complete blood count, a white blood cell count (5.100/ $\mathrm{mm}$ ), renal and kidney function tests, a urine analysis, and a lower abdominal ultrasound and computerized tomography (CT) examinations. All the test results were within the normal reference values. Ultrasound examination revealed a thickness of the appendiceal wall as $3 \mathrm{~mm}$, which was also within the previously determined normal range. Abdominal CT examination showed the thickening of the appendiceal wall and the fluid accumulation inside its lumen (Figure 1).

As an advanced and invasive procedure we performed a colonoscopic examination, however could not gather any additional finding. On the suspicious diagnosis of a chronic appendicitis we performed a laparotomy and examined the appendix. Its appearance, colour and size were similar with the small intestine (Figure 2). We performed appendectomy and besides the usual post operative treatment we ordered a daily single dose of $1 \mathrm{gr}$ Cefazolin sodium. On the post-operative first day the patient began oral alimentation. On the fourth postoperative day he was discharged with full recovery. The final diagnosis was confirmed by the pathological examination, as the chronic appendicitis.

\section{Discussion}

Appendicitis with or without its complications are seen in all age groups, especially in children and young adults. In addition, the surgical removal of the appendix is required for the management of the most of the cases ${ }^{8}$.

Acute appendicitis manifests as a feeling of abdominal distension and pain. The symptoms are the results of the obstruction of the appendiceal lumen which leads to the development of the inflammation and the distension of the appendix. In some cases, the over distended wall of the appendix perforates and the inflammatory contents spreads through the surrounding tissue, while in some other cases the inflammatory process is localized and it is held among the peripheral tissue causing the formation of a phlegmon ${ }^{9,10}$.

Appendiceal luminal obstruction results from the lymphoid hyperplasia secondary to the infectious process in children and adults, however it results from a fecalithis in elder patients. Parasites, foreign bodies and neoplasias may occasionally cause appendicitis.

Clinical manifestation of the entity is similar in many cases, independent of the etiology. Generally first symptom is the peri-umbilical pain, and then the pain spreads towards the right lower abdominal quadrant and finally it is localized in the right lower abdominal quadrant. On palpation, the signs of tenderness and rebound may be revealed. Although some patients may benefit from the antibiotic treatment, in most cases the definitive treatment is the surgical removal of the appendix $8,11,12$.

Chronic pain in the right lower abdominal quadrant may be misdiagnosed, particularly in childhood and puberty. It is because the chronic pelvic pain may be a component of various clinical situations. It may be associated with several diseases such as irritable bowel syndrome or dilated pelvic veins complicated with vascular hyperesthesia ${ }^{13,14}$.

Recurrent abdominal pain is a major problem frequently seen in childhood and only $10 \%$ of them can be related with an organic disorder ${ }^{1}$. Patient history, physical examination and the laboratory work-up are generally adequate for a correct diagnosis of appendicitis, however in rare cases an imaging modality is also needed.

In one third of the cases of acute appendicitis the clinical findings are not typical and the tenderness is not associated with the pain in the right lower quadrant of the abdomen. There is no nausea or vomiting and the body temperature and the white blood cell count may be in the normal reference levels ${ }^{15}$.

The chronic appendicitis does not manifest with the classical symptoms of the acute appendicitis and it is usually diagnosed secondary to the histo-pathological examination. Persistent and recurrent abdominal pain is the usual indication for the surgery ${ }^{7}$.

Stroh et al. determined a 35\% chronic appendicitis rate diagnosed histopathologically in their laparotomy 


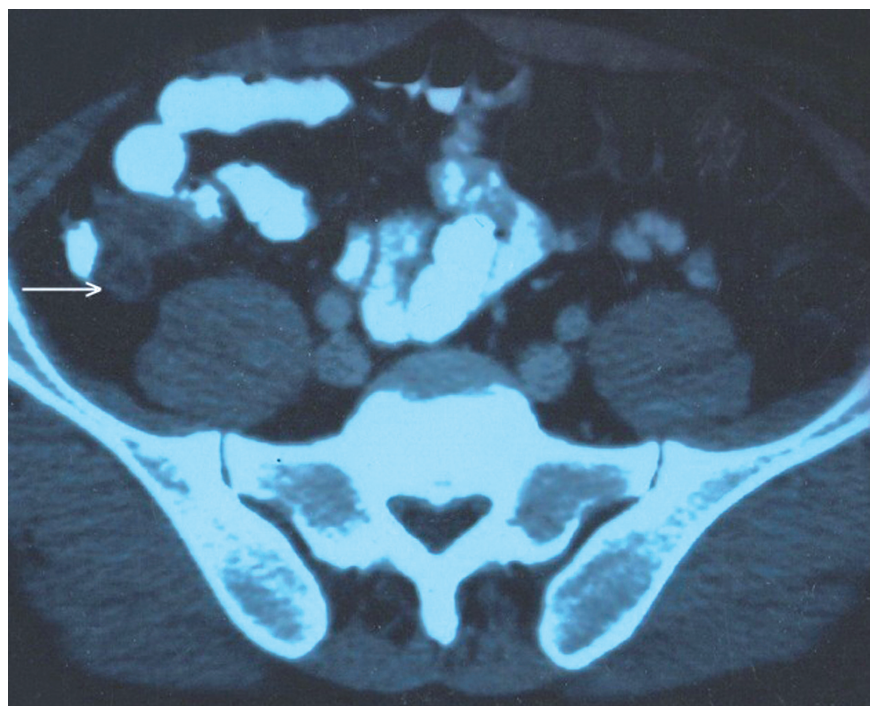

Figure 1. Axial computerized tomography image demonstrated the increased appendiceal wall thickness and the fluid accumulation in the lumen of the appendix.

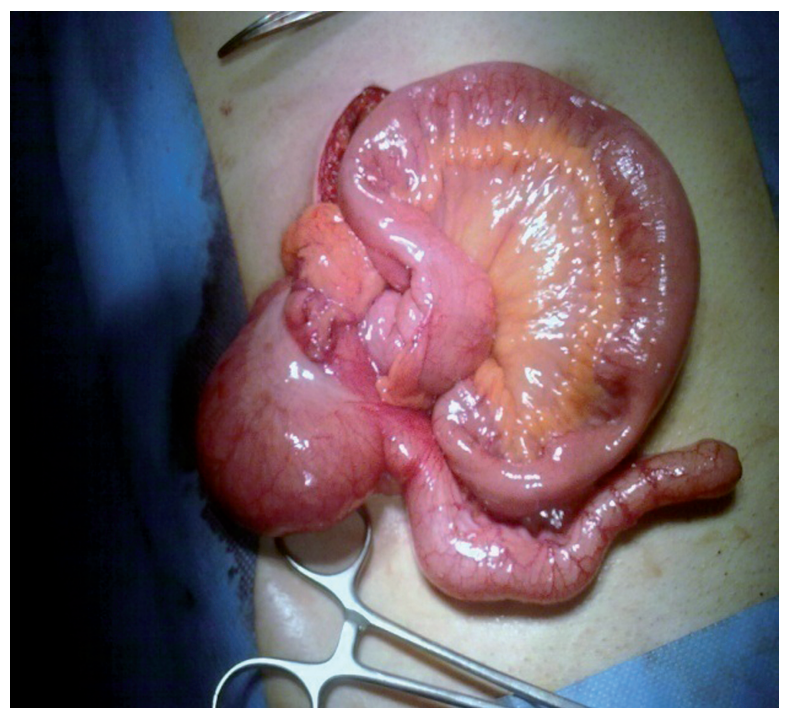

Figure 2. The appearance, colour and size of the operated appendix looked liked as the small intestine. It was significantly dilated. series performed with the indication of abdominal pain. In the same study, they found an appendicitis rate of $83 \%$ in children experiencing no abdominal pain. Montiel-Jarquín et al. also reported a chronic appendicitis case having similarities with our case. The patient had appendectomy and the diagnosis was assured following the histopathological examination ${ }^{16}$.

In a study conducted by Savrin et al., $16 \%$ of a total of 225 patients were diagnosed with the chronic or subappendicitis. However, the chronic abdominal pain and histopathological confirmation was achieved only in four patients. Recurrent abdominal pain episodes was present in nine patients and they were diagnosed with acute suppurative appendicitis after the hisopathological examination.

In conclusion, chronic appendicitis does not manifest with classical clinical symptoms and signs of acute appendicitis. In the evolution of the chronic and recurrent abdominal pain, the chronic appendicitis must always be considered as one of the probable pathological conditions.

\section{References}

1. Gorenstin A, Serour F, Katz R, et al. Appendiceal colic in children: a true clinical entity? J Am Coll Surg 1996; 182: 246-50.

2. Paudel GR, Agrawal CS, Regmi R, et al. Conservative treatment in acute appendicitis. JNMA J Nepal Med Assoc 2010; 180: 295-9.

3. Lau WY, Fan ST, Yiu TF, et al. Negative findings at appendectomy. Am J Surg 1984; 148:375-8.
4. Tehrani HY, Petros JG, Kumar RR, et al. Markers of severe appendicitis. Am Surg 1999; 65: 453-5.

5. Blomqvist PG, Andersson RE, Granath F, et al. Mortality after appendectomy in sweden, 1987-1996. Ann Surg 2001; 233: 455-60.

6. Savrin RA, Clausen K, Martin EW Jr, et al. Chronic and recurrent appendicitis. Am J Surg 1979; 137:355-7.

7. Mussack T, Schmidbauer S, Nerlich A, et al. Chronic appendicitis as an independent clinical entity. Chirurg 2002; 73: $710-5$.

8. Condon RE, Telford GL. Appendicits. In: Sabiston DC. Textbook of Surgery. 14th ed. Philadelphia, 1991: 884- 98.

9. Ghelase F, Georgescu I, St Ghelase M, et al. Septic complications in acute appendicitis. Problems of diagnosis and treatment. Chirurgia (Bucur) 2007; 102: 43-9.

10. Ikeda $H$, Ishimaru $Y$, Takayasu $H$, et al. Laparoscopic versus open appendectomy in children with uncomplicated and complicated appendicitis. J Pediatr Surg 2004; 39: 1680-5.

11. Walker AR, Segal I. What causes appendicitis? J Clin Gastroenterol 1990; 12: 127-9.

12. Green SM, Schmidt SP, Rothrock SG. Delayed appendicitis from an ingested foreign body. Am J Emerg Med 1994; 12: 53-5.

13. Pandza H, Custovic S, Covic R, et al. Laparoscopic treatment of lower abdominal pain related to chronic appendicitis. Med Arh 2008; 62: 268-70.

14. Stroh C, Rauch J, Schramm H. Is there a chronic appendicitis in childhood? Analysis of pediatric surgical patients from 1993-1997. Zentralbl Chir 1999; 124:1098-102.

15. Rahime Yüksekkaya, Erol Akgül, Mehmet İnal, et al. Akut apandisit tanısında kontrastsız spiral BT'nin yeri. Tanısal ve Girişimsel Radyoloji 2004; 10: 131-9.

16. Montiel-Jarquín AJ, Gómez-Conde E, Reyes-Páramo P, et al. Chronic appendicitis. A case report. Rev Med Inst Mex Seguro Soc 2008; 46: 431-4. 